Research, part of a Special Feature on Understanding the Vulnerability and Sustainability of Urban Social-Ecological Systems in the Tropics: Perspectives from the City of San Juan

\title{
Plant species richness and abundance in residential yards across a tropical watershed: implications for urban sustainability
}

\author{
Cristina P. Vila-Ruiz ${ }^{1}, \underline{\text { Elvia Meléndez-Ackerman }}^{1,2}, \underline{\text { Raul Santiago-Bartolomei }}^{3}$, Diana Garcia-Montiel $^{2}, \underline{\text { Lourdes Lastra }}^{4}, \underline{\text { Cielo E }}^{\text {. }}$ \\ Figuerola $^{1}$ and $\underline{\text { Jose Fumero-Caban }}^{2,4}$
}

\begin{abstract}
Green spaces within residential areas provide important contributions to the sustainability of urban systems. Therefore, studying the characteristics of these areas has become a research priority in cities worldwide. This project evaluated various aspects of the plant biodiversity of residential yards (i.e., front yards and back yards within the Río Piedras watershed in the San Juan metropolitan area of Puerto Rico). Our work included gathering information on vegetation composition and abundance of woody species (i.e., trees, shrubs, palms, ferns) and large herbs (>2 m height), species origin (native vs. introduced), and species uses (ornamental, food, and medicinal plants). A total of 424 yards were surveyed within an area of $187,191 \mathrm{~m}^{2}$. We found 383 woody species, with shrubs being the most abundant plant habitat. As expected, residential yards hosted a disproportionate amount of introduced species (69.5\%). The most common shrub species were all non-native ornamentals, whereas the most common tree species included food trees as well as ornamental plants and two native species. Front yards hosted more ornamental species per unit area than backyards, while the latter had more food plants. The high amount of introduced species may present a challenge in terms of implementation of plant conservation initiatives if there is no clear definition of urban conservation goals. On the other hand, the high frequency of yards containing food plants may facilitate the development of residential initiatives that could provide future adaptive capacity to food shortages.
\end{abstract}

Key Words: backyards; ecosystem services; front yards; plant diversity; residential landscapes; residential green spaces; tropical watersheds; urban systems; urban sustainability

\section{INTRODUCTION}

Researchers worldwide are beginning to recognize the potential contribution of residential landscapes and yards to overall urban sustainability (Goddard et al. 2009, Owen 2010). In the past, these were often ignored, primarily because of their small scale. But this view is quickly changing (Shackleton et al. 2008, Goddard et al. 2009). The benefits of residential vegetation may be variable, in terms of providing ecosystem services such as food supplies, mitigation of urban heat island and urban fragmentation effects, runoff reduction, and above-ground carbon storage; as well, residential vegetation may have positive effects on the quality of human life, health, and well-being (Dunnett and Qasim 2000, Town and Country Planning Association 2004, Williams et al. 2009, Cilliers et al. 2011, Davies et al. 2011, Cameron et al. 2012). In some areas, the structural diversity of the vegetation in residential yards can be a good predictor of biological diversity in the urban environment (Müller et al. 2010). As such, more scientists are now recognizing that green spaces in urban areas may have positive effects not only on the quality of life and wellbeing of humans (Dunnett and Qasim 2000), but also on overall urban biodiversity and ecological richness (Benedict and McMahon 2006, Smith et al. 2006a, Müller et al. 2010).

Recent reviews have highlighted the biotic characterization of urban residential areas as a research priority in many areas around the world ( Dunn and Heneghan 2011, Cilliers et al. 2012, Cook et al. 2012). Floristic information from private residential spaces can provide valuable information about the quality of private gardens as resources for urban biodiversity (Smith et al. 2006b, Thompson et al. 2003). It can also offer information about the functionality of yards based on the services that plant species may be providing by being ornamental, nutritional, or medicinal
(Akinnifesi et al. 2010). Studies of residential yards with a biodiversity focus are more common in northern temperate cities located in industrialized countries, whereas studies where the emphasis is on the services provided by yard plants are more common in developing countries and mostly in rural areas (Cilliers et al. 2012 and references therein). Although geographical coverage has increased in biodiversity studies of residential yards, tropical cities - especially in Latin Americaare still largely underrepresented in urban biodiversity studies (but see: Mexico City, Mexico: Díaz-Betancourt 1987; León, Nicaragua: González-García and Gómez-Sal 2008; São Luís, Brazil: Akinnifesi et al. 2010). In the city of São Luís (Brazil), native plants are still the largest component of residential yards (Akinnifesi et al. 2010). This is a pattern that contrasts with almost all temperate cities studied (Dunn and Henegan 2011) and emphasizes the need to expand the geographic focus of biodiversity studies in residential yards. At a local scale, evaluating the differences in the relative contribution of front yards vs. backyards to biodiversity is another understudied aspect of green residential areas (Daniels and Kirkpatrick 2006, Cook et al. 2012). Vegetation differences between these two areas may be linked to differences in the functionality of yards, which could help us understand the factors that may be driving urban biodiversity dynamics at the household scale.

In this study we characterized the biodiversity of residential areas within the Río Piedras watershed in the Caribbean island of Puerto Rico. This system is largely contained within the municipality of San Juan (capital city of Puerto Rico) where it is the largest watershed. San Juan is the largest urban area of the island of Puerto Rico with 395,326 inhabitants (U.S. Census Bureau 2010). Urban expansion in this island and in the city of

${ }^{1}$ Department of Environmental Sciences, University of Puerto Rico at Río Piedras, ${ }^{2}$ Center for Applied Tropical Ecology and Conservation, University of Puerto Rico at Río Piedras, ${ }^{3}$ Graduate School of Planning, University of Puerto Rico at Río Piedras, ${ }^{4}$ Department of Biology, University of Puerto Rico at Río Piedras 
San Juan proceeded rapidly since the 1950 s due to the dramatic economic changes generated by a transition from agricultural to industrial production (López and Villanueva 2006, RiveraSantana et al. 2006). Several studies have evaluated the biodiversity of public green spaces of San Juan, and at least two were conducted within the Río Piedras watershed (reviewed in Lugo et al. 2011), but until now the potential contribution of private spaces to the overall biodiversity of this site has remained unexplored. Only $29 \%$ of the Río Piedras watershed green land cover is classified as forest and pastures (Jesús-Crespo and Ramírez 2010) which emphasizes the potential role of green residential spaces to the ecological richness of this system and to the overall green infrastructure of the city of San Juan.

In this study we evaluated plant species diversity in residential areas and their potential contribution to the sustainability of the Río Piedras watershed by addressing the following questions: (1) What is the composition, richness, and abundance of plant species in residential yards in the Río Piedras watershed? (2) Are there differences in the frequencies of native and introduced plant species in residential yards in the Río Piedras watershed? (3) What are the predominant utilitarian roles of plant species within residential yards in the Río Piedras watershed? (4) Are residential front yards and backyards in the Río Piedras watershed homogeneous in their contribution to the watershed's plant abundance and species richness? (5) Do front yards and backyards vary in their functional characteristics, whether the plant usage is ornamental, nutritional, medicinal, or some other use?

Evaluating the biodiversity status of residential green spaces is the first step in the development of planning initiatives that integrate multiple sustainability goals, including species conservation and food security practices. Our study focused on the overall quality of green space within the context of plant species composition and plant abundance provided by the conglomerate of sampled residential green spaces.

\section{STUDY SITE}

Study areas were located within the Río Piedras watershed, which has an area of 49,000 $\mathrm{m}^{2}$ and covers the municipalities of San Juan, Guaynabo, and Trujillo Alto (Lugo et al. 2011). The Río Piedras River originates in the Cupey sector at about $150 \mathrm{~m}$ of elevation and flows north for $16,000 \mathrm{~m}$ until it reaches the coast. The river itself has undergone extensive geomorphological changes, with large segments having been diverted, channelized, and even buried for the construction of urban infrastructure (Lugo et al. 2011). Based on the life zone system of Holdridge (1967) the ecosystem of the Río Piedras watershed would be classified as a subtropical moist forest zone (Ewel and Whitmore 1973). Mean annual rainfall in the watershed ranges from 1509 $\mathrm{mm}$ on the coast and 1509 to $1755 \mathrm{~mm}$ upland; mean annual temperatures for Río Piedras have been reported at $25.7^{\circ} \mathrm{C}$ (Lugo et al. 2011). Geological formations within the watershed include urban fill, mangroves and swamp, alluvium, limestone, and inclusive and volcaniclastic rocks, which cover $>50 \%$ of the area (Webb and Gómez-Gómez 1998). The Río Piedras watershed presents a land cover gradient that ranges from high-density, urban build-up near the coast (lower watershed region) to forest cover around the headwaters (higher watershed region; RamosGonzález et al. 2005).

\section{METHODS}

\section{Design}

Our study was carried out at six permanent study plots along the urban cover gradient of the Río Piedras watershed established by San Juan ULTRA (Urban Long-Term Research Areas, Fig. 1; Seguinot-Barbosa and Hernández-García 2012). General household sampling followed a stratified sampling scheme with the initial selection of locations based on a general representation of the rural-urban gradient of gray area coverage and the inclusion of certain plots based on ongoing studies within the San Juan ULTRA Project. These locations were named and described as follows: San Patricio: high urban cover, lower watershed location elevation; Puerto Nuevo: high urban cover, lower watershed location; Avenida Central: mid-watershed location, high urban cover; La Sierra: mid-watershed location, intermediate urban cover; Cupey: upper watershed location, low urban cover; and Chiclana: upper watershed location, low urban cover. Within each location we randomly selected access roads and within each road we surveyed all possible households up to a minimum of 60 households/site. This sampling scheme generated a total of 424 households (fronts yards visited $=424$; backyards visited $=379$ ) that ranged from 60 to $80 /$ study plot as follows: San Patricio $(\mathrm{n}=60)$; Puerto Nuevo $(\mathrm{n}=67)$; Chiclana $(n=65) ;$ La Sierra $(n=73)$; Cupey $(n=79)$, and Avenida Central $(n=80)$. Fig. 2 provides examples of the variety of yardscapes that can be encountered throughout the watershed. This diversity reflects the variety of neighborhood concepts and morphologies that are embedded within the San Juan metropolitan area and promoted by the public and private sector as well as aided by the rural perception that owing land is indispensable (Municipio Autónomo de San Juan 2003). The Puerto Nuevo site contains the first massive single-family housing project (Puerto Nuevo) on the island with over 4000 units, each on $252 \mathrm{~m}^{2}$ parcels. Houses are small and many yards have been heavily paved (Fig. 2A). Another type of residential neighborhood morphology resulted from the allocation of ample land to individuals or groups of individuals, who were then responsible for building their own houses. Houses in these urban morphology types are physically different from one another (dominant morphology in Avenida Central, Cupey, Chiclana, Fig. 2B and 2D). In contrast, residential areas in Avenida Central and residential sites in Cupey and Chiclana tend to occur in rustic soil, along secondary and tertiary roads. Massive and highly planned residential sites developed by the private sector proliferated after the 1970s and dominate urban complexes in La Sierra (Fig. 2C) and San Patricio, with San Patricio showing a higher abundance in multifamily housings relative to the other study sites. Most households surveyed were single-family housing units, which dominate the Río Piedras watershed residential areas, but the survey also included seven "yards" associated with multifamily housing units and three associated to public multifamily housing. The socioeconomic profile of households was varied and representative of the socioeconomic diversity within the Río Piedras watershed. Fifty-five percent of the residents that granted access were married; they were also predominantly female $(60 \%$ of residents) with an age span that ranged from 18 to 96 years of age (average age $=56.4 \mathrm{y}$ ) and a span of number of years of formal education that ranged from 0 to 23 years (average $=13.7 \mathrm{y}$ ). The 
average household income was also variable, with the average household mid-income being $\$ 32,769$.

Fig. 1. Locations of six of the thirteen sampling locations across the Río Piedras watershed that were studied by San Juan ULTRA.

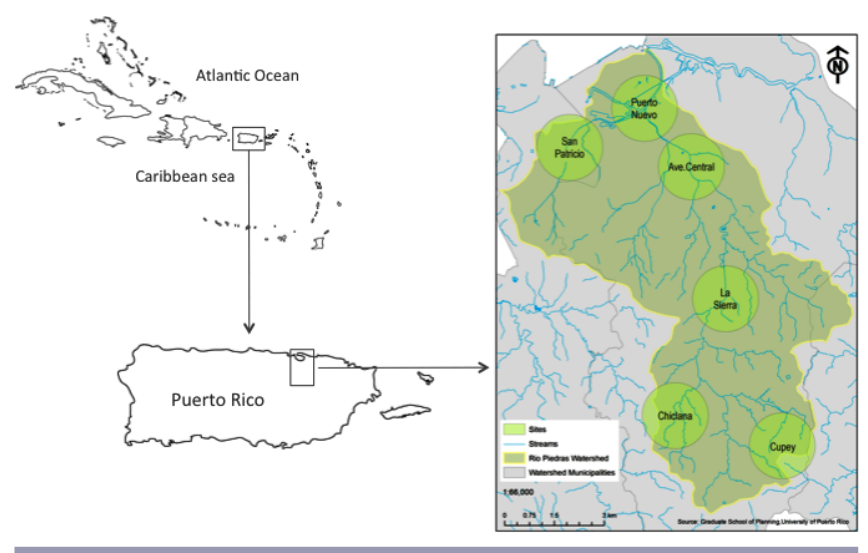

Fig. 2. Examples of the variety of yardscapes observed within the Rio Piedras watershed and associated with single-housing units at each study. (A) Over-paved front yard, Puerto Nuevo. (B) Mostly lawn, front yard, Avenida Central. (C) Mixed shrubs and trees, La Sierra. (D) Highly forested yards, Cupey.

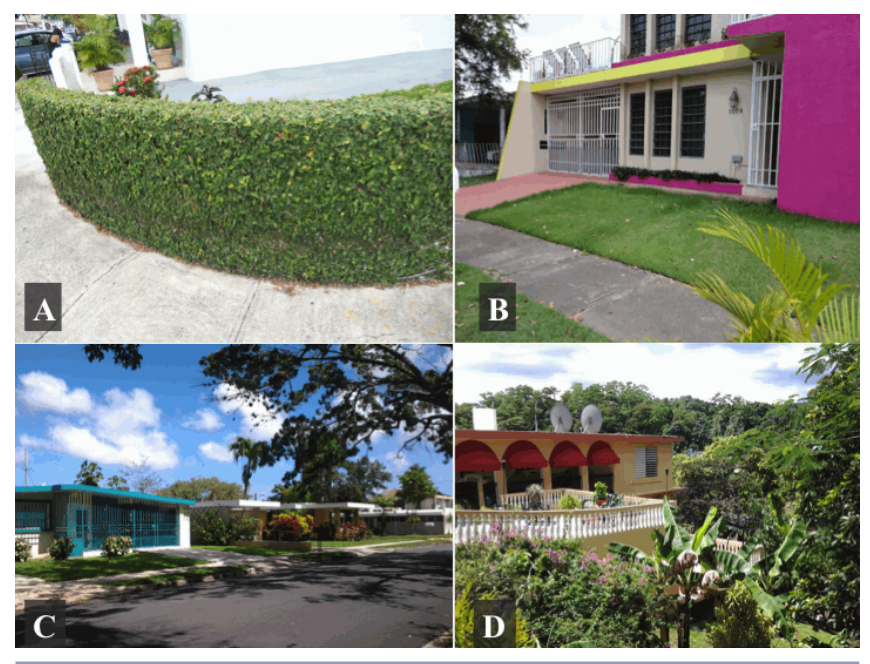

\section{Vegetation survey}

At each household we conducted a vegetation survey of the front yard and the backyard when access was granted. Surveys were conducted between January 2011 and July 2011, with an additional survey conducted in October of 2011. In each yard we recorded woody plant species richness and abundance (i.e., trees, shrubs, palms, tree ferns). For each yard we also recorded the total yard area. Area measurements were estimated using Google Earth Pro version 7.0 (Google 2012). All plants recorded were photographed and identified in the field when possible, with identifications verified by local botanists. All species were classified according to native or introduced origin, and utilitarian role for food, ornamental, or medicinal. Some species did not have roles that fell into these categories and were classified as having alternative uses. These uses included soil erosion control, rehabilitation of disturbed lands, wood, and craft materials. Most species classifications were based on two plant database websites: The PLANTS Database (National Plant Data Team 2013) and the Germplasm Resources Information Network (National Genetic Resources Program 2013). These were complemented by taxonomic literature (Nuñez-Meléndez 1964, Little et al. 1974, Miner-Solá 1998, Liogier and Martotell 2000, Rivero and Brunner 2006, Rivero 2009).

\section{Statistical analyses}

Accumulation curves (PC-ORD version 5 (McCune and Mefford 1999)) were used to evaluate overall species richness in residential yards across the watershed and to test for differences between the average cumulative numbers of native vs. introduced species. Species accumulation curves were also used to evaluate differences in species richness among the different utilitarian species classifications. We used a contingency analysis to evaluate differences in the frequency of introduced and native species and the frequency of plant stems (i.e., plant abundance) across the different plant categories: trees, shrubs, palm-ferns, and large herbs. In this and the following analyses, palms and ferns were collapsed into one category due to their small sample sizes. We tested for differences in the density of stems and species per yard across sites with a one-way ANOVA followed by Tukey-Kramer mean comparisons. We used Non-Parametric Multidimensional Scaling Ordination (NMS) (PC-ORD version 5.0, McCune and Mefford 1999) to evaluate if there were differences in overall species composition between the different watershed localities given the known variability in ecological conditions throughout the watershed (Lugo et al. 2011) based on a species matrix that included abundance values for each species encountered. For this analysis we used Bray-Curtis, a random starting configuration, and 40 iterations with real data and 50 iterations with randomized data to select a dimensionality, and then we performed 500 iterations with the chosen dimensionality to find a stable solution with minimal stress (McCune et al. 2002). We also evaluated differences between front yards and backyards in average density of species stems of ornamentals, food plants, medicinals, and plants with other uses by running paired t-tests (JMP version 7 , SAS Institute Inc. 2007) on individual variables. These categories were assigned based on a literature review of the species observed.

\section{RESULTS AND DISCUSSION}

\section{Vegetation composition}

A total of 22,785 stems and 383 plants species that included trees, shrubs, palms, ferns, and herbs $>2 \mathrm{~m}$ were detected among the 424 households surveyed within an area of $187,191 \mathrm{~m}^{2}$. We observed significant differences in the density of stems but not in the density of species per yard across sites (Figs. 3 and 4). Yards at Cupey had the higher abundance of stems and species relative to other sites in the watershed, while yards in Puerto Nuevo and Avenida Central had the lowest abundance of species per yard. Regarding overall species composition, NMS analyses indicated that within-site variation in yard species, composition was higher than variation among sites, and that as a result, all six sites exhibited similar patterns of variation in species composition (Fig. 5). Of the 383 species encountered, 69.5\% were introduced 
Fig. 3. Frequency of species per yard across sites within the Rio Piedras watershed. Species density: F5,405 $=1.95, \mathrm{p}=0.09$.

Different letters indicate significant differences among sites at $\mathrm{p}$ $<0.05$ using Tukey-Kramer tests.

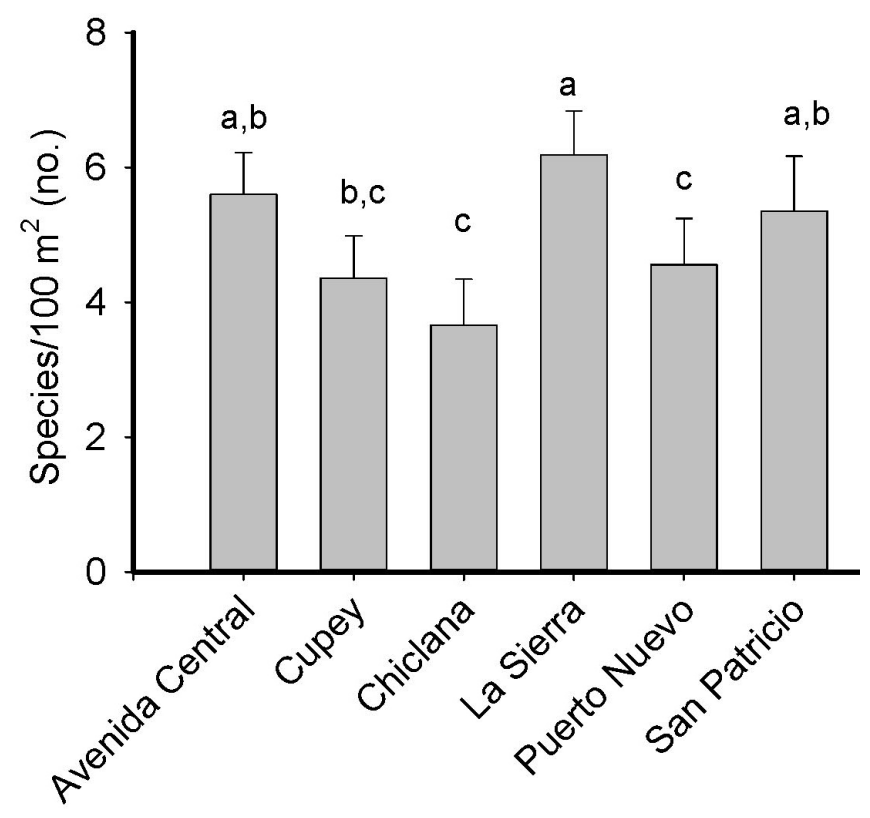

Sites
Fig. 4. Frequency of stems per yard across sites within the Rio Piedras watershed. Stem density: F5,405 $=2.29, \mathrm{p}=0.04$.

Different letters indicate significant differences among sites at $\mathrm{p}$ $<0.05$ using Tukey-Kramer tests.

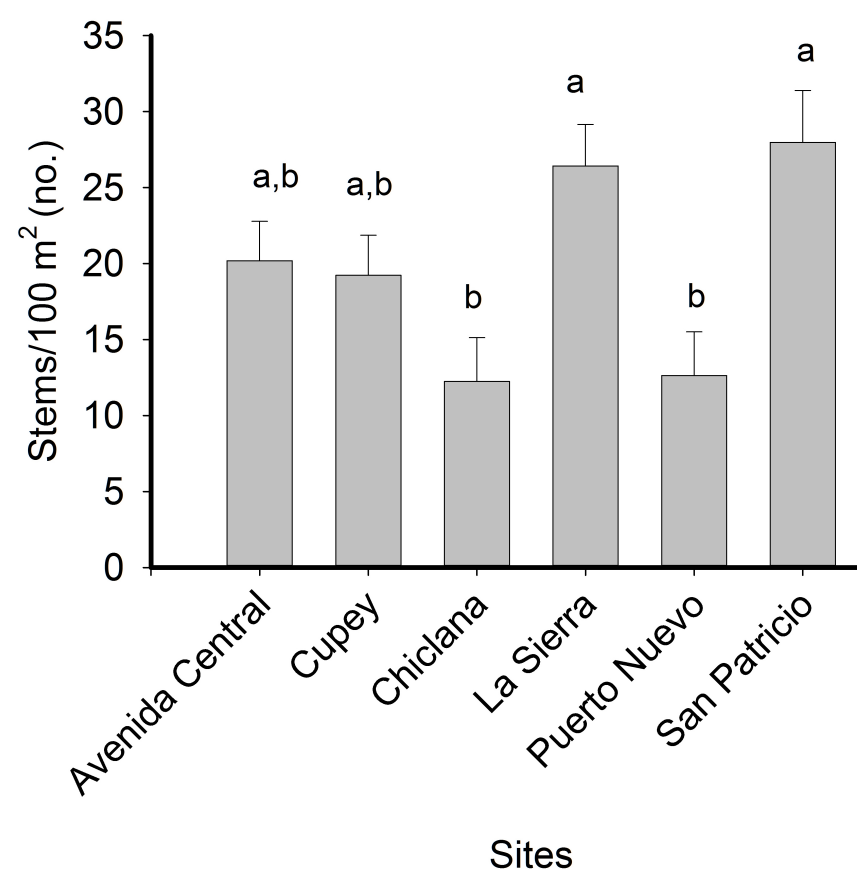

(Fig. 6), with the majority of species being ornamentals, at $64 \%$. Food plants accounted for $15.7 \%$ and medicinal uses for $11.2 \%$, and other uses for $9.1 \%$ (Fig. 7). While there were more species of trees and shrubs relative to other plant forms (Table 1A), shrubs were the most abundant plant across the watershed with $45.5 \%$ of the stems recorded, followed by trees ( $22 \%$ of stems), large herbs $(24.5 \%)$, and palms and ferns at $8 \%$ of the stems surveyed (Table 1B). Species accumulation curves clearly suggest that the expected number of species provided by residential areas is higher than the observed because the pooled species accumulation curve did not reach an asymptote (Fig. 6). Species-sample curves for introduced and native species also failed to reach an asymptote, but the difference between the two curves, which follows approximately a two-to-one ratio, seems to have reached stability (Fig. 6).

Ornamental species presented the highest species accumulation rate with $64 \%$ of the species (Fig. 7) and $69.1 \%$ of the stems, followed by food plants $(15.1 \%$ of the species and $24.5 \%$ of the stems). Plants with medicinal and other uses combined provided $19.3 \%$ of the species but only $7.9 \%$ of the total stems. Despite these differences in the relative number of species of ornamental and food plants, we found that the 10 most common ornamental species had only slightly higher stem abundances and frequencies of occurrence across households relative to food plants across the watershed (Table 2). The most common ornamentals were the Asian tropical shrubs Ixora coccinea (Cruz de Malta) and Codiaeum variegatum (croton) both of which occurred in at least
Fig. 5. NMS Ordination evaluating variation among Río Piedras watershed sites in species composition. The variation in plant composition is equally represented across sites and there are no side difference in overall species composition.

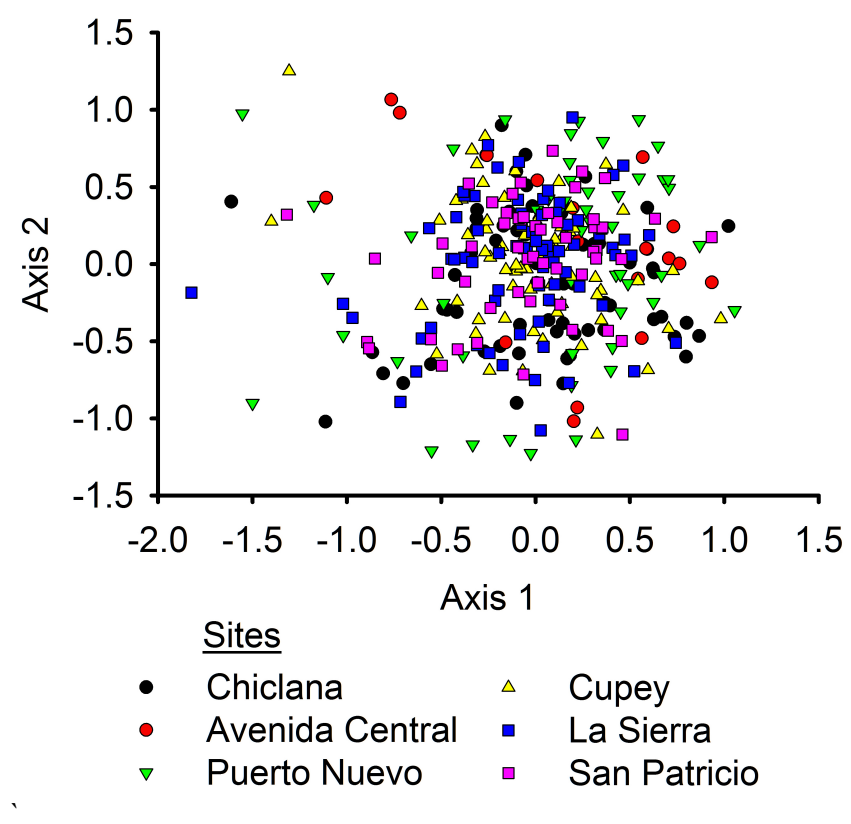


Table 1. Chi-squared test of heterogeneity to evaluate differences in plant origin.

\begin{tabular}{|c|c|c|c|c|c|}
\hline Criteria & Origin & Trees & Shrubs & $\begin{array}{l}\text { Palms- } \\
\text { ferns }\end{array}$ & Herbs \\
\hline $\begin{array}{l}\text { Species } \\
x^{2}=9.3,\end{array}$ & $\begin{array}{l}\text { Natives } \\
\text { Introduced } \\
=3, \mathrm{p}=0.03\end{array}$ & $\begin{array}{c}63 \\
103\end{array}$ & $\begin{array}{c}37 \\
105\end{array}$ & $\begin{array}{c}6 \\
31\end{array}$ & $\begin{array}{l}11 \\
27\end{array}$ \\
\hline $\begin{array}{l}\text { Stems } \\
x^{2}=891,\end{array}$ & $\begin{array}{l}\text { Natives } \\
\text { Introduced } \\
=3, \mathrm{p}<0.0\end{array}$ & $\begin{array}{l}1010 \\
4001 \\
1\end{array}$ & $\begin{array}{c}664 \\
9669\end{array}$ & $\begin{array}{c}142 \\
1715\end{array}$ & $\begin{array}{c}315 \\
5269\end{array}$ \\
\hline
\end{tabular}

Fig. 6. Species accumulation curves based on data for 424 households across the Río Piedras watershed, based on origin (native and non-native).

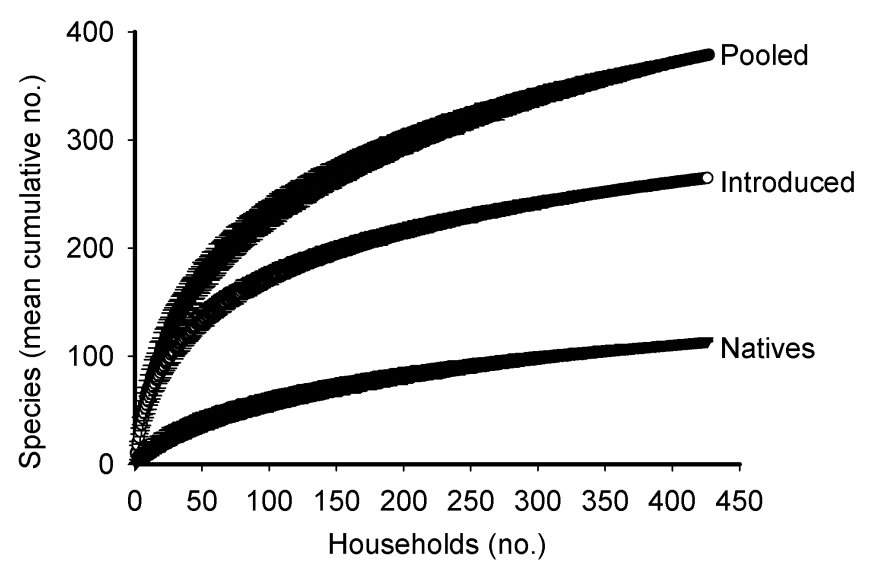

$39 \%$ of the households. The most common food plants-Musa acuminata (bananas), Persea americana (avocado), and Citrus aurantifolia (lime) - were all present in at least $25 \%$ of the households. In the utilitarian roles (food, medicinal, and other uses), trees were the most frequent plant forms, in contrast to ornamentals in which case shrub forms dominated. (Table 2). Out of the 40 most-common species, only nine were native. All of the ten most-common ornamentals were introduced species (Table 2; http://sanjuanultra.com/recurso/most-abundant-species/). The most common native species had either medicinal or other uses, and all but one of the native species, the tree Annona muricata (soursop), occurred at $<6 \%$ of the households.

Paired t-test analyses indicated clear differences in the richness and abundance of species of ornamental and food plants between front yards and backyards (Fig. 8 and 9). Front yards had more ornamental species per unit area than backyards, while backyards had more food species. Similarly, the density of ornamental plants was highest in front yards, while that of food plants was highest in backyards. There were no significant differences in the density of species or stems, for neither medicinal plants nor plants with other uses.
Fig. 7. Species accumulation curves based on data for 424 households across the Río Piedras watershed, based on utilitarian role.

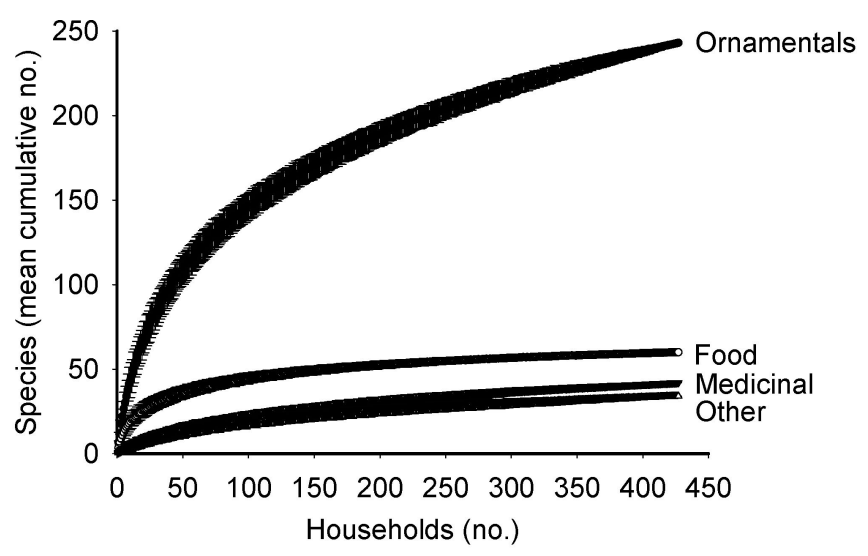

Plant species richness and abundance patterns observed at the Río Piedras watershed were consistent with some of the common features shared by urban residential green areas world-wide. One feature is that they support a great number of species (Kumar and Nair 2006, Gaston 2010) and, in some cases, these may host more species than natural and seminatural landscapes (Thompson et al. 2003, Wania et al. 2006, Lubbe et al. 2010). Our results were consistent with these findings. For example, Río Piedras watershed households maintained a considerable number of woody species (348 species) that included 166 tree species. This value was higher than that reported for the entire subtropical moist life zone in Puerto Rico to which Río Piedras watershed belongs (130 species in 120,600 $\mathrm{m}^{2}$ sampled; Brandeis et al. 2007), and it was much higher than in areas of natural regeneration sampled by prior studies within the Río Piedras watershed (e.g., riparian corridors, 14 tree species in $4050 \mathrm{~m}^{2}$ sampled in Lugo et al. 2001; and urban karst, 29 species in $1900 \mathrm{~m}^{2}$ sampled in Suárez et al. 2005). None of the 40 most-common species present within residential yards occurred in $>41 \%$ of the households, and the majority-343 out of 383 species - were present in $<7 \%$ of the Río Piedras watershed households. Thus, residential areas are important contributors to urban species richness and plant composition heterogeneity in the watershed of the city of San Juan. The fact that species-sample curves failed to stabilize in our study (Figs. 6 and 7) suggests that the species richness of perennials in the Río Piedras watershed is likely underestimated, particularly for ornamental plants (Fig. 7).

\section{Non-native species}

Floristic analyses for many cities suggest that urban areas also support a large number of non-native species (Smith et al. 2006b, Loram et al. 2008, Dunn and Heneghan 2011 and references therein) and that this rate is especially high for residential yards (Mckinney 2006, Smith et al. 2006b). The level of non-native plants supported by residential yards at the Río Piedras watershed $(69.3 \%)$ was indeed higher than that reported for urban natural and seminatural areas in the city of San Juan (San Patricio Forest: 24.1\% in Suárez et al. 2005, 47.9\% in Lugo and Brandeis 2005). 
Table 2. Relative frequency of the ten most abundant species for each utilitarian role in Río Piedras watershed. Relative frequency values were calculated based on the total number of houses visited $(n=424)$.

\begin{tabular}{|c|c|c|c|c|c|c|}
\hline Utilitarian role & Species name & Origin & Category & $\begin{array}{c}\text { Stems } \\
\text { (no.) }\end{array}$ & $\begin{array}{c}\text { Houses } \\
\text { (no.) }\end{array}$ & $\begin{array}{l}\text { Relative frequency } \\
\qquad(\%)\end{array}$ \\
\hline \multirow{10}{*}{ Ornamental } & Ixora coccinea & Non-native & Shrub & 2263 & 173 & 40.52 \\
\hline & Codiaeum variegatum & Non-native & Shrub & 1446 & 165 & 38.64 \\
\hline & Cordyline fruticosa & Non-native & Shrub & 784 & 119 & 27.87 \\
\hline & Dracaena marginata & Non-native & Shrub & 354 & 99 & 23.19 \\
\hline & Schefflera arboricola & Non-native & Shrub & 456 & 82 & 19.20 \\
\hline & Hibiscus rosa-sinensis & Non-native & Shrub & 307 & 76 & 17.80 \\
\hline & Dypsis lutescens & Non-native & Palm & 420 & 75 & 17.56 \\
\hline & Adonidia merrilli & Non-native & Palm & 252 & 69 & 16.16 \\
\hline & Alpinia purpurata & Non-native & Herb & 1067 & 66 & 15.46 \\
\hline & Dracaena fragans & Non-native & Shrub & 264 & 62 & 14.52 \\
\hline \multirow[t]{10}{*}{ Food } & Musa acuminata & Non-native & Herb & 2605 & 147 & 34.43 \\
\hline & Persea americana & Non-native & Tree & 278 & 125 & 29.27 \\
\hline & Citrus aurantifolia & Non-native & Tree & 204 & 123 & 28.81 \\
\hline & Mangifera indica & Non-native & Tree & 213 & 93 & 21.78 \\
\hline & Citrus paradisi & Non-native & Tree & 188 & 92 & 21.55 \\
\hline & Cocos nucifera & Non-native & Palm & 330 & 83 & 19.44 \\
\hline & Carica papaya & Non-native & Tree & 212 & 77 & 18.03 \\
\hline & Musa accxbal & Non-native & Herb & 826 & 73 & 17.10 \\
\hline & Psidium guajava & Non-native & Tree & 122 & 73 & 17.10 \\
\hline & Annona muricata & Native & Tree & 100 & 71 & 16.63 \\
\hline \multirow[t]{10}{*}{ Medicinal } & Calophyllum antillanum & Non-native & Tree & 96 & 21 & 4.92 \\
\hline & Morinda citrifolia & Non-native & Tree & 26 & 20 & 4.68 \\
\hline & Pimenta racemosa & Native & Tree & 34 & 19 & 4.45 \\
\hline & Jatropha curcas & Non-native & Shrub & 27 & 18 & 4.22 \\
\hline & Ochna jabotapita & Non-native & Tree & 34 & 16 & 3.75 \\
\hline & Ardisia elliptica & Non-native & Shrub & 48 & 14 & 3.28 \\
\hline & Lepianthes peltata & Native & Shrub & 39 & 10 & 2.34 \\
\hline & Piper aduncum & Native & Shrub & 35 & 8 & 1.87 \\
\hline & Solanum torvum & Non-native & Tree & 37 & 8 & 1.87 \\
\hline & Jatropha gossypiifolia & Non-native & Shrub & 18 & 6 & 1.41 \\
\hline \multirow[t]{10}{*}{ Alternate } & Spathodea campanulata & Non-native & Tree & 502 & 70 & 16.39 \\
\hline & Casearia guianensis & Native & Tree & 68 & 22 & 5.15 \\
\hline & Cecropia schreberiana & Native & Tree & 69 & 18 & 4.22 \\
\hline & Albizia procera & Non-native & Tree & 31 & 14 & 3.28 \\
\hline & Swietenia mahagoni & Non-native & Tree & 29 & 13 & 3.04 \\
\hline & Albizia lebbeck & Non-native & Tree & 33 & 11 & 2.58 \\
\hline & Swietenia macrophylla & Non-native & Tree & 20 & 11 & 2.58 \\
\hline & Schefflera morototoni & Native & Tree & 22 & 10 & 2.34 \\
\hline & Andira inermis & Native & Tree & 56 & 8 & 1.87 \\
\hline & Bambusa arundinacea & Non-native & Herb & 57 & 7 & 1.64 \\
\hline
\end{tabular}

Most studies of urban biodiversity that have a focus on private residential gardens have been based on temperate cities of developed countries, and report non-native species rates ranging from 68 to $71 \%$ (e.g., Gaston et al. 2005, Kinzig et al. 2005, Loram et al. 2008; also reviewed in Cilliers et al. 2012). In many cities, a high rate of non-natives has often been linked to a large number of ornamentals species (Acar et al. 2007) introduced through a globalized nursery trade (Ignatieva 2012). Analog studies that focus on the biodiversity characterization of private gardens in tropical Latin American cities are extremely scarce, and those now available reflect a wider range of variation in the proportion of non-native species maintained by households (e.g., 40\% in São Luís Brazil, Akinnifesi et al. 2010; 58\% in León Nicaragua, González-García and Gómez-Sal 2008; 70\% in Mexico City, Mexico, Diaz-Betancourt et al. 1987; 69.9\% in this study). The city of São Luís has a notable lower proportion of non-native plant species, and researchers suggest that a preponderance of household owners with rural origins who have kept a cultivation tradition of local plants to meet their different personal needs may explain the higher rate of native species in these urban yards 
Fig. 8. Paired t-tests evaluating differences between front yards and backyards in abundance of plants, by utilitarian roles. Error bars represent standard errors around the mean and (*) indicate significant tests at $\mathrm{p}$ values $<0.0001$.

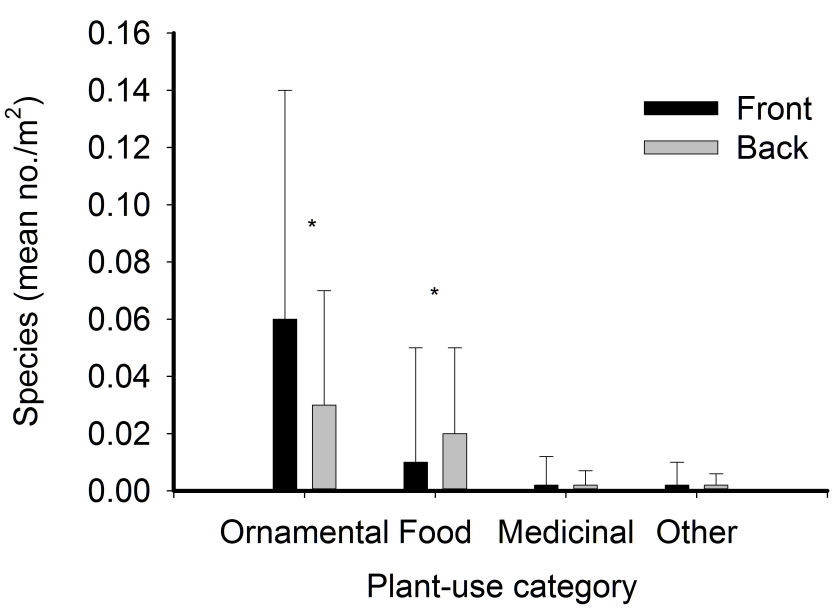

Fig. 9. Paired t-tests evaluating differences between front yards and backyards in plant species richness, by utilitarian role. Error bars represent standard errors around the mean and (*) indicate significant tests at $\mathrm{p}$ values $<0.0001$.

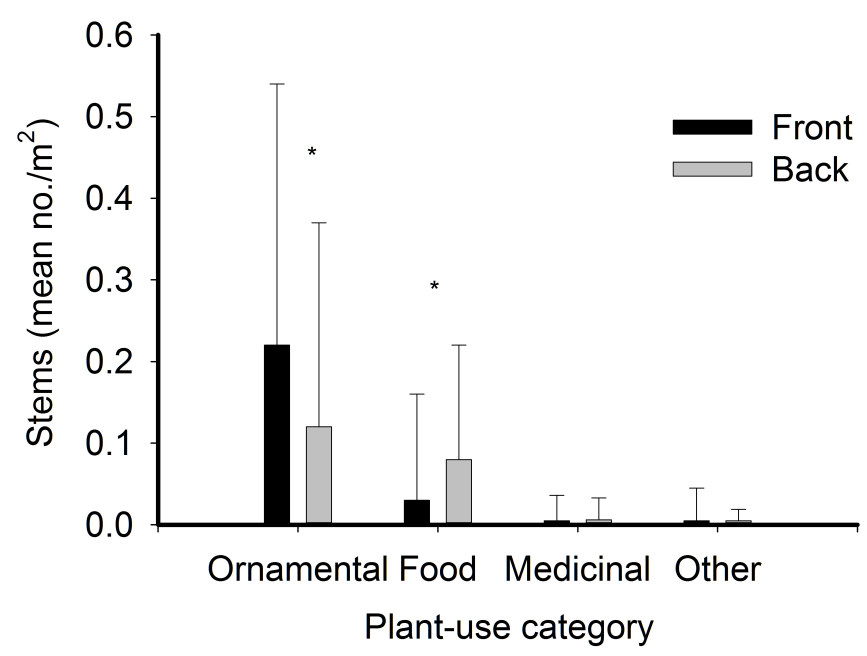

(Akinnifesi et al. 2010). Despite the general observations that urban agriculture constitutes an important activity in tropical cities (Pullido et al. 2008, Akinnifesi et al. 2010), residential yards with characteristics of a "tropical home garden" (i.e., yards with a food consumption role; Das and Kumar-Das 2005, Kumar and Nair 2006, Pullido et al. 2008) are not necessarily the norm in all tropical cities.

\section{Rare and common species}

At the scale of the watershed we were unable to detect spatial differences in the species composition of yards across sampling sites, which were dominated by a few species but populated with many rare ones. Food plants found in the Río Piedras watershed yards, such as Citrus sp., Psidium guajava (guava), Cocos nucifera (coconut), Carica papaya (papaya), Mangifera indica (mango), and Persea americana are a common fixture of tropical residential yards around the world (Blanckaert et al. 2004, Albuquerque et al. 2005, Das and Kumar-Das 2005, Kumar and Nair 2006, Pullido et al. 2008, Buchmann 2009, Eichemberg et al. 2009, Bigirimana et al. 2012). Likewise many of the common ornamental species observed at Río Piedras watershed yards like those within the genera Hibiscus, Bougainvillea, and Cordyline happen to be common elements of modern nurseries around the world (Ignatieva 2012). These species are part of a pool of species from different areas of the world that are kept in commercial nurseries as part of a trend that began in nineteenth century England in connection with the popularization of tropical and subtropical plants in English Victorian garden styles (Ingatieva 2010, 2012). This reduced pool of ornamentals now dominate many tropical urban landscapes and has led to a standardization of urban landscape styles in a process that has been criticized as one that has led to "placeless" urban designs, a potential lost "sense of place" (Bowring et al. 2009), a reduced ecological uniqueness of urban sites, and the cultural homogenization of urban landscapes (Ignatieva and Stewart 2009, Ignatieva 2010). Based on our results, one could argue that there is a standardization of yards across the Río Piedras watershed in terms of the most common plant materials. This process appears to have occurred rapidly, given that the introduction of ornamental shrubs in Puerto Rico can be traced only to the beginning of the twentieth century (Hume 1951) and also because it was only in the 1970s that the ornamental plant industry showed an increased economic strength (Valentín-Esteves 1975).

Front yards and backyards: differences

Our results clearly showed structural differences between front yards and backyards related to differences in richness and abundance of plants associated to different uses. These differences most likely relate to differences in functionality between these yard spaces. Front yards in the Río Piedras watershed, most of which are unfenced and readily visible to the public, had a higher diversity and concentration of ornamentals. In contrast, backyards, the majority of which are fenced and not visible from the streets, had the highest concentration and diversity of food plants. At least one study has documented changes in species composition and potential differences in the functionality of front yards and backyards; whereas front yards tended to be showier and backyards had a higher concentration of productive activities (Daniels and Kirkpatrick 2006). In general, most urban ecological studies of residential yards in urban areas have focused (for practical reasons) on the ecological features of front yards and much less is known about the ecological characteristics of backyards (Cook et al. 2012). At least two studies have discussed how differences in socioeconomic factors (especially income) across households may in turn lead to differences in landscape preferences and landscape behaviors for front yards and backyards (e.g., lower-income households preferring front lawns, some residents preferring tidy front yards while having backyards 
with messy appearances; Grove et al. 2006, Larsen and Harlan 2006). Socioeconomic status of households may also influence not only yard diversity but also the relative distribution of native and introduced residential plants (Lubbe et al. 2010). A necessary follow-up to this study is evaluating how socioeconomic factors at the household scale influence yard management and evaluating the actual contribution of ecosystem services by households.

The San Patricio and La Sierra households yielded the highest stem densities per unit area. Not only are these residential communities adjacent to urban protected areas but they have also actively participated in their legal protection, in their development, and in the implementation of conservation goals (Law No. 260 2004; Departamento de Recursos Naturales y Ambientales 2008). These sites are likely to be associated with a variety of social and economic factors that would need to be explored in order to understand how, and if, social traits associated with environmental concern at a wider scale also help to shape residential landscapes at the household scale.

\section{CONCLUSION}

Scientific communities have been exploring the potential of residential green spaces as an opportunity to complement local biodiversity-conservation strategies, ecosystem service,s and other aspects of urban sustainability (Cameron et al. 2012). From the perspective of biodiversity conservation the high numbers of introduced species in residential yards in the Río Piedras watershed presents a great challenge. While these numbers are commonly found in temperate cities, the very low frequency of native plants across households in the watershed $(<6 \%)$ most likely reinforces cultural links between residents and introduced ornamentals. Local conservation initiatives supporting native tree plantings should evaluate resident vegetation preferences in a variety of attributes that could then help select appropriate native species in landscape planning. With respect to plant biodiversity, however, it may be argued that a low abundance of any given species is likely to make species less apparent to herbivores and pathogens (Thompson et al. 2003). Thus, any initiative favoring the transition to native plants would also benefit from gathering scientific evidence on the services of natives and the disservices of non-native ones (if any). A current argument that has scientific support, at least in temperate cities, is that a higher number of native species should offer better provisioning services through the improvement of the function of plant-animal interactions, for example, pollination and herbivory, within residential gardens (Tallamy 2007, Cross and Spence 2009). For example, one study has reported a decrease in native butterfly populations as a result of their interactions with non-native plants in urban areas (Bergerot et al. 2010, Raupp et al. 2010). Another study found that urban properties with a higher non-native cover supported a significantly lower caterpillar abundance and diversity and, concomitantly, a lower diversity and abundance of birds (Burghardt et al. 2009). From an ecosystem service perspective, non-native species may perform services (e.g., low-cost reforestation, aesthetics) in urban settings just as well as native plants under certain circumstances (Dearborn and Kark 2010). The existence of multiple and, sometimes, conflicting motivations for the conservation of urban biodiversity would require that conservation goals (i.e., composition vs. function) be clearly defined, with the involvement of all potential stakeholders (Dearborn and Kark 2010, Goodard et al. 2013). Local initiatives that favor the conservation of native species would benefit from data on how native and non-native species contribute to the overall urban fauna biodiversity at the Río Piedras watershed and from an evaluation of services that these can provide to help define these goals.

Aside from the high number of species, the presence of food plants in a large number of yards across the Río Piedras watershed may provide adaptive capacity mechanisms to changes in food security. Rates of food imports have reached an all-time high of $80 \%$ in Puerto Rico, suggesting a highly vulnerable urban society (Comas-Pagán 2009). Under such circumstances a variety of local agricultural strategies, including food production in residential yards, should be encouraged. This is a strategy that has been extremely important to the residents in the island of Cuba, because it was a measure to ensure food security following major changes in their economic and political circumstances in the 1990s (Buchmann 2009). Clearly, properly studying the dynamics of residential areas and how they relate to human choices and behaviors requires an evaluation of how yard characteristics vary in relation to a variety of social factors and how current yard configurations relate to urban ecosystem services. Through the San Juan ULTRA network we are currently evaluating the links between yard biodiversity features and socioeconomic factors and how these links may explain the observed variation in residential green spaces across the Río Piedras watershed. These types of analyses can be particularly useful in the evaluation of factors that contribute to the vulnerability and sustainability of the San Juan metropolitan area and in evaluating how these factors could help us study the dynamics of this tropical city (Goddard et al. 2013).

Responses to this article can be read online at: http://www.ecologyandsociety.org/issues/responses. $\mathrm{php} / 6164$

\section{Acknowledgments:}

This research was supported by NSF-REU (DBI-1062769), NSFULTRA (DBI-0948507), The Institute for Tropical Ecosystem System Studies (ITES), and the Center for Applied Tropical Ecology and Conservation (CATEC, NSF-CREST: HRD-0206200) of the University of Puerto Rico, Rio Piedras Campus. We are grateful for the cooperation of many volunteers and students of the $U P R$ system who helped in every stage of the research, and in particular we are grateful to the residents of San Juan and Guaynabo who made the collection of field data possible. We also thank $A$. Lugo, M. Alayón, and M. Pérez for helpful comments on this manuscript.

\section{LITERATURE CITED}

Acar, C., H. Acar, and E. Eroğu. 2007. Evaluation of ornamental plant resources to urban biodiversity and cultural changing: a case study of residential landscapes in Trabzon city (Turkey). Building and Environment 42:218-229.

Akinnifesi, F. K., G. Sileshi, J. da Costa, E. G. de Moura, R. F. da Silva, O. C. Ajayi, J. F. P. Linhares, A. I. Akinnifesi, M. de 
Araujo, and M. A. I. Rodrigues. 2010. Floristic composition and canopy structure of home-gardens in São Luís city, Maranhão State, Brazil. Journal of Horticulture and Forestry 2:72-86.

Albuquerque, U. P., L. H. C. Andrade, and J. Caballero. 2005. Structure and floristics of homegardens in Northeastern Brazil. Journal of Arid Environments 62:491-506. http://dx.doi. org/10.1016/j.jaridenv.2005.01.003

Benedict, M. A., and E. T. McMahon. 2006. Green infrastructure: linking landscapes and communities. Island Press, Washington D. C., USA.

Bergerot, B., B. Fontaine, M. Renard, A. Cadi, and R. Julliard. 2010. Preferences for exotic flowers do not promote urban life in butterflies. Landscape and Urban Planning 96:98-107. http://dx. doi.org/10.1016/j.landurbplan.2010.02.007

Bigirimana, J., J. Bogaert, C. D. Cannière, M. J. Bigendako, and I. Parmentier. 2012. Domestic garden plant diversity in Bujumbura, Burundi: role of the socio-economical status of the neighborhood and alien species invasion risk. Landscape and Urban Planning 107:118-126. http://dx.doi.org/10.1016/j.

landurbplan.2012.05.008

Blanckaert, I., R. L. Swennen, M. Paredes Flores, R. Rosas López, and R. Lira Saade. 2004. Floristic composition, plant uses and management practices in homegardens of San Rafael Coxcatlán, Valley of Tehuacán-Cuicatlán, Mexico. Journal of Arid Environments 57:39-62. http://dx.doi.org/10.1016/S0140-1963 (03)00100-9

Bowring, J., S. Egoz, and M. Ignatieva. 2009. As good as the West: two paradoxes of globalization and landscape architecture in St. Pietersburg. Journal of Landscape Architecture 90:6-15. http://dx. doi.org/10.1080/18626033.2009.9723409

Brandeis, T. J., E. H. Helmer, and S. N. Oswalt. 2007. The status of Puerto Rico's forests, 2003. USDA, Forest Service, Southern Research Station, Asheville, North Carolina, USA.

Buchmann, C. 2009. Cuban home gardens and their role in socialecological resilience. Human Ecology 37:705-721. http://dx.doi. org/10.1007/s10745-009-9283-9

Burghardt, K. T., D. W. Tallamy, and W. G. Shriver. 2009. Impact of native plants on bird and butterfly biodiversity in suburban landscapes. Conservation Biology 23:219-224. http://dx.doi. org/10.1111/j.1523-1739.2008.01076.x

Cameron, R. W. F., T. Blanusa, J. E. Taylor, A. Salisbury, A. J. Halstead, B. Henricot, and K. Thompson. 2012. The domestic garden-its contribution to urban green infrastructure. Urban Forestry \& Urban Greening 11:129-137.

Cilliers, S., S. Siebert, E. Davoren, and R. Lubbe. 2011. Social aspects of urban ecology in developing countries, with an emphasis on urban domestic gardens. Applied Urban Ecology: A Global Framework 123-138. http://dx.doi.org/10.1002/9781444345025. $\underline{\operatorname{ch} 10}$

Cilliers, S., S. Siebert, E. Davoren, and R. Lubbe. 2012. Social aspects of urban ecology in developing countries, with an emphasis on urban domestic gardens. Pages 123-138 in M. Richter and U. Weiland, editors. Applied urban ecology: a global framework. Willey and Blackwell, Oxford, UK.
Comas-Pagan, M. 2009.Vulnerabilidad de lascadenau de suministros, el cambioclimático y el desarrollo de estrategias de adaptación: El caso de lascadenas de suministros de alimentos de Puerto Rico. Thesis. University of Puerto Rico Rio Piedras Campus, San Juan, Puerto Rico. [online] URL: http://academic. uprm.edu/mcomas/HTMLobj-159/tesis.pdf

Cook, E. M., S. J. Hall, and L. K. Larson. 2012. Residential landscape as social-ecological systems: a synthesis of multi-scalar interactions between people and their home environment. Urban Ecosystems 15:19-52. http://dx.doi.org/10.1007/s11252-011-0197-0

Cross R., and R. Spence. 2009. Sustainable gardens. CSIRO Publishing, Collingwood, Australia.

Daniels, G. D., and J. B. Kirkpatrick. 2006. Comparing the characteristics of front and back domestic gardens in Hobart, Tasmania, Australia. Landscape and Urban Planning 78:344-352. http://dx.doi.org/10.1016/j.landurbplan.2005.11.004

Das, T., and A. Kumar-Das. 2005. Inventorying plant biodiversity in homegardens: a case study in Barak Valley, Assam, North East India. Current Science 89:155-163

Davies, Z. G., J. L. Edmondson, A. Heinemeyer, J. R. Leake, and K. J. Gaston. 2011. Mapping an urban ecosystem service: quantifying above-round carbon storage at a city-ide scale. Journal of Applied Ecology 48:1125-1134. http://dx.doi. org/10.1111/j.1365-2664.2011.02021.x

Dearborn D. C., and S. Kark. 2010. Motivations for conserving urban biodiversity. Conservation Biology 24:432-440. http://dx. doi.org/10.1111/j.1523-1739.2009.01328.x

Departamento de Recursos Naturales y Ambientales. 2008. Bosques de Puerto Rico: Bosque de San Patricio. Hojas de Nuestro Ambiente P026. DNRA, Estado Libre Asociado de Puerto Rico. [online] URL: http://www.drna.gobierno.pr/biblioteca/publicaciones/ hojas-de-nuestro-ambiente/26-San\%20Patricio.pdf

Díaz-Betancourt, M., I. López-Moreno, and E. H. Rapoport. 1987. Vegetación y ambienteurbano en la Ciudad de Mexico. Pages 13-72 in E. H. Rapoport and I. López-Moreno, editors. Las plantas de los jardinesprivados, Aportes a la Ecología Urbana de la Ciudad de México. Limusa, México.

Dunn, C. P., and L. Heneghan. 2011. Section 2.4 Composition and diversity of urban vegetation. Pages 103-114 in J. Niemelä, editor. Urban ecology: patterns, processes, and applications. Oxford University Press, New York, USA.

Dunnett, N., and M. Qasim. 2000. Perceived benefits to human well-being of urban gardens. HortTechnology 10(1):40-45. [online] URL: http://horttech.ashspublications.org/content/10/1/40. full.pdf

Eichemberg, M. T., M. C. de Mello-Amorozo, and L. C. D. Moura. 2009. Species composition and plant use in old urban homegardens in Rio Claro, Southeast of Brazil. Acta Botanica Brasilica 23:1057-1075. http://dx.doi.org/10.1590/ $\underline{\text { S0102-33062009000400016 }}$

Ewel, J. J., and J. L. Whitmore. 1973. The ecological life zones of Puerto Rico and the U.S. Virgin Islands. Research Paper ITF-108. USDA, Forest Service, Institute of Tropical Forestry, Río Piedras, Puerto Rico. 
Gaston, K. J. 2010. Urban ecology. Cambridge University Press, Cambridge, England. http://dx.doi.org/10.1017/CBO9780511778483

Gaston K. J., P. H. Warren, K. Thompson, and R. M. Smith. 2005. Urban domestic gardens (IV): the extent of the resource and its associated features. Biodiversity Conservation 14:3273349.

Goddard, M. A., A. J. Dougill, and T. G. Benton. 2009. Scaling up from gardens: biodiversity conservation in urban environments. Trends in Ecology \& Evolution 25:90-98. http://dx. doi.org/10.1016/j.tree.2009.07.016

Goddard, M. A., A. J. Dougill, and T. G. Benton. 2013. Why garden for wildlife? Social and ecological drivers, motivations and barriers for biodiversity management in residential landscapes. Ecological Economics 86:258-273. http://dx.doi.org/10.1016/j. ecolecon.2012.07.016

González-García A., and A. Gomez-Sal. 2008. Private urban spaces or "patios" as a key element of urban ecology in tropical America. Human Ecology 36:291-300. http://dx.doi.org/10.1007/ $\underline{\mathrm{s} 10745-007-9155-0}$

Google. 2012. Google Earth Pro. Version 7.0. Google Inc., Mountain View, California, USA.

Grove, J. M., A. R. Troy, J. P. O’Neil-Dunne, W. R. Burch, M. L. Cadenasso, and S. T. A. Pickett. 2006. Characterization of households and its implications for the vegetation of urban ecosystems. Ecosystems 9(4):578-597.

Holdridge, L. R. 1967. Life zone ecology. Tropical Science Center, San José, Costa Rica.

Hume, B. 1951. Some ornamental shrubs for the tropics. Circular No. 34. USDA, Federal Experiment Station, Mayagüez, Puerto Rico.

Ignatieva, M. 2010. Design and future of urban biodiversity. Pages 118-144 in N. Muller, P. Werner and J. G. Kelcey, editors. Urban biodiversity and design. Wiley-Blackwell, Oxford, England. http://dx.doi.org/10.1002/9781444318654.ch6

Ignatieva, M. 2012. Plant material for urban landscapes in the era of globalization: roots, challenges and innovative solutions. Pages 139-151 in M. Richter and U. Weiland, editors. Applied Urban Ecology. Willey and Blackwell, Oxford, England. http://dx.doi. org/10.1002/9781444345025.ch11

Ignatieva, M., and V. Stewart. 2009. Globalization trends in Russian landscape architecture. Pages 111-115 in M. Stewart, I. Ignatieva, J. Bowring, S. Egoz, and I. Melnichuck, editors. Globalization of landscape architecture: issues for education and practice. St. Petersburg State Polytechnic University Publishing House, St. Petersburg, Russia.

Jesús-Crespo, R., and A. Ramírez. 2010. The use of a Stream Visual Assessment Protocol to determine ecosystem integrity in an urban watershed in Puerto Rico. Physics and Chemistry of the Earth, Parts $A / B / C$ 36(12):560-566.

Kinzig, A. P., P. Warren, C. Martin, D. Hope, and M. Katti. 2005. The effects of human socioeconomic status and cultural characteristics on urban patterns of biodiversity. Ecology and Society 10(1):23.
Kumar, B. M., and P. K. R. Nair. 2006. Tropical home gardens: a time-tested example of sustainable agroforestry. Springer, Dordrecht, The Netherlands.

Larsen, L., and S. L. Harlan. 2006. Desert dreamscapes: residential landscape preference and behavior. Landscape and Urban Planning 78:85-100. http://dx.doi.org/10.1016/j. landurbplan.2005.06.002

Law No. 260.2004. Ley paraenmendar la Ley Núm. 206 de 2003: Para incluir el Arboretum de Cupey en el CorredorEcológico de San Juan. ( P. del S.2414). LexJuris Puerto Rico. [Online] URL: http:// www.lexjuris.com/lexlex/Leyes2004/lex12004260.htm

Liogier, Alain H., and Luis F. Martorell. 2000. Flora of Puerto Rico and adjacent islands: a systematic synopsis. Editorial Universidad de Puerto Rico, San Juan, Puerto Rico.

Little, E. L., R. O. Woodbury, and F. H. Wadsworth. 1974. Trees of Puerto Rico and the Virgin Islands: second volume. Agriculture Handbook No. 449. USDA, Washington D.C., USA.

López-Marrero, T., and N. Villanueva-Colón. 2006. Atlas Ambiental de Puerto Rico. Editorial Universidad de Puerto Rico, San Juan, Puerto Rico.

Loram A., P. H. Warren, and K. J. Gaston. 2008. Urban domestic gardens (XIV): the characteristics of gardens in five cities. Environmental Management 42:361-376. http://dx.doi.org/10.1007/ $\underline{\mathrm{s} 00267-008-9097-3}$

Lubbe, C. S., S. J. Siebert, and S. S. Cilliers. 2010. Political legacy of South Africa affects the plant diversity patterns of urban domestic gardens along a socio-economic gradient. Scientific Research and Essay 5:2900-2910.

Lugo, A. E., and T. J. Brandeis. 2005. A new mix of alien and native species coexist in Puerto Rico's landscapes. Pages 484-509 in D. F. R. P. Burslem, M. A. Pinard, S. E. Hartley, editors. Biotic interactions in the tropics: their role in the maintenance of species diversity. Cambridge University Press. Cambridge, UK.

Lugo, A. E., O. Ramos, and C. Rodríguez-Pedraza. 2011. Description of the Rio Piedras River watershed and its surrounding environment. FS-980. International Institute of Tropical Forestry, USDA, Forest Service, Jardín Botánico Sur, San Juan, Puerto Rico.

Lugo, S., B. Bryan, and L. Reyes, A. E. Lugo. 2001. Riparian vegetation of a subtropical urban river. Acta Cientifica 15:59-72.

McCune, B., Grace, J. B., and Urban, D. L. 2002. Analysis of ecological communities. MjM Software Design, Gleneden Beach, Oregon, USA.

McCune, B, and M. J. Mefford. 1999. PC-ORD: multivariate analysis of ecological data. Version 5. MjM Software, Gleneden Beach, Oregon, USA.

McKinney, M. L. 2006. Urbanization as a major cause of biotic homogenization. Biology Conservation 127:247-260. http://dx. doi.org/10.1016/j.biocon.2005.09.005

Miner-Solá, Edwin. 1998. Flores de Puerto Rico y exóticas. Vol. 4. EdicionesServilibros, Madrid, Spain. 
Müller, N., P. Werner, and J. G. Kelcey. 2010. Urban biodiversity and design. Conservation Science and Practice Series No. 7. Blackwell Publishing Ltd., Oxford, England. http://dx.doi. org/10.1002/9781444318654

Municipio Autonomo de San Juan. 2003. Reglamento de ordenacion territorial, Municipio de San Juan. Tomo III.

National Genetic Resources Program. 2013. Germplasm Resources Information Network-(GRIN). Agricultural Research Service, U.S. Department of Agriculture, Beltsville, Maryland, USA. [online] URL: http://www.ars-grin.gov/

National Plant Data Team. 2013. The PLANTS Database. National Resources Conservation Service, U.S. Department of Agriculture, Greensboro, North Carolina, USA. [online] URL: http://plants.usda.gov/java/

Negrón, L., C. P. Vila, E. Meléndez-Ackerman. Las especies de plantas más abuntantes en los patios residenciales de la cuenca del Rio Piedras, Puerto Rico [Most abundant plant species in residential yards in the Rio Piedras Watershed, Puerto Rico]. Presentation. Centro de Datos, San Juan Ultra, USDA Forest Service and National Science Foundation, San Juan, Puerto Rico. [online] URL: http://sanjuanultra.org/recurso/most-abundantspecies/

Núñez-Meléndez, E. 1964. Plantasmedicinales de Puerto Rico. Editorial Universidad de Puerto Rico. San Juan, Puerto Rico.

Owen, J. 2010. Wildlife of a garden: a thirty-year study. Royal Horticultural Society. Peterborough, Cambridgeshire, UK.

Pullido, M. T., E. M. Pagaza-Calderón, A. Martínez-Ballesté, B. Maldonado-Almanza, A. Saynes, and R. M. Pacheco. 2008. Home gardens as an alternative for sustainability: challenges and perspectives in Latin America. Pages 55-79 in U.P. Albuquerque and Marcelo Alves Ramos, editors. Current topics in ethnobotany. Research Signpost, Kerala, India.

Ramos-González, O. M., C. D. Rodríguez-Pedraza, A. E. Lugo, and B. Edwards. 2005. Distribution of forests and vegetation fragments in the San Juan metropolitan area. Pages 111 in T. W. Zimmerman, V. Combie, C. C. Clarke, editors. Proceedings of the 9th Annual Caribbean Urban Forestry Conference: Managing the Caribbean Urban and Community Forest, June 14-18, 2004. Coperative Extension Service, University of the Virgin Islands, St. John, U.S. Virgin Islands.

Raupp, M. J., P. M. Shrewsbury, and D. A. Herms. 2010. Ecology of Herbivorous Arthropods in Urban Landscapes. Annual Review of Entomology 55:19-38 http://dx.doi.org/10.1146/annurevento-112408-085351

Rivera-Santana, J. E., W. Crespo, Y. Graxirena, J. Castañer, L. Adames, and R. Cruz. 2006. El Estado de la Infraestructura Verde en Puerto Rico: Pasado, Presente y Futuro. Pages 33-56 in D. Morales- Rodríguez, editors. Infraestructuraverde y nuestrosparques. Compañía de Parques Nacionales de Puerto Rico. Lajas, Puerto Rico.

Rivero, J. A. 2009. El libro de las hojas distinguidas. La Editorial, Universidad de Puerto Rico. San Juan, Puerto Rico.

Rivero, J. A., and Bryan R. Brunner. 2006. Árbolesfrutalesexóticos y pococonocidos en Puerto Rico. La Editorial, Universidad de Puerto Rico. San Juan, Puerto Rico.
SAS Institute Inc. 2007 JMP. Version 7. Cary, North Carolina, USA.

Seguinot-Barbosa, J. S., R. Hernández-García. Metodologíapara el diseño de muestreo socio-ecológico en la Cuenca del ríoPiedras: San Juan, Puerto Rico. [online] URL: http://www.inegi.org.mx/ eventos/2011/conf ibero/doc/ET6 40-SEGUINOT.pdf

Shackleton, C. M., F. Paumgarten, and M. L. Cocks. 2008. Household attributes promote diversity of tree holdings in rural areas, South Africa. Agroforestry System 72:221-230. http://dx. doi.org/10.1007/s10457-007-9066-5

Smith, R. M., K. J. Gaston, P. H. Warren, and K. Thompson. 2006a. Urban domestic gardens (VIII): environmental correlates of invertebrate abundance. Biodiversity and Conservation $15: 2515-2545$.

Smith, R. M., K. Thompson, G. J. Hodgson, P. H. Warren, and K. J. Gaston. 2006b. Urban domestic gardens: composition and richness of the vascular plant flora, and implications for native biodiversity. Biological Conservation 129:312-322.

Suárez, A., I. Vicéns, and A. E. Lugo. 2005. Composición de especies y estructura del bosquekárstico de San Patricio, Guaynabo, Puerto Rico. ActaCientífica 19:7-22.

Tallamy, D. 2007. Bringing nature home: how native plants sustain wildlife in our gardens. Timber Press Inc., Oregon, USA.

Thompson, K., K. C. Austin, R. M. Smith., P. H. Warren., P. G. Arnold, and K. J. Gaston. 2003. Urban domestic gardens (I): putting small-scale plant diversity in context. Journal of Vegetation Science 14: 71-78. http://dx.doi.org/10.1658/1100-9233 (2003)014[0071:UDGIPS]2.0.CO;2

Town and Country Planning Association. 2004. Biodiversity by design: a guide for sustainable communities. London, UK. [online] URL: http://www.tcpa.org.uk/data/files/bd biodiversity.pdf

U.S. Census Bureau. 2010. 2010 census interactive population search: PR - San Juan Municipio. U.S. Department of Commerce, Washington, D.C., USA.

Valentín-Esteves, H. 1975. Perspectiva en la producción de plantas ornamentals. Revista Agricultura de Puerto Rico 50:35-38.

Wania A., I. Kühn, and S. Klotz. 2006. Plant richness patterns in agricultural and urban landscapes in Central Germany-spatial gradients of species richness. Landscape and Urban Planning 57:97-110. http://dx.doi.org/10.1016/j.landurbplan.2004.12.006

Webb, R. M. T., and F. Gómez-Gómez. 1998. Synoptic survey of water quality and bottom sediments, San Juan Bay estuary system, Puerto Rico, December 1994-July 1995. Water-Resources Investigations Report 97-4144. U.S. Geological Survey, U.S. Department of the Interior, San Juan, Puerto Rico.

Williams, N. S. G., M. W. Schwartz, P. Vesk, M. A. McCarthy, A. K. Hahs, S. E. Clemants, R. T. Corlett, R. P. Duncan, B. A. Norton, K. Thompson, and M. J. McDonnell. 2009. A conceptual framework for predicting the effects of urban environments on floras. Journal of Ecology 97:4-9. http://dx.doi.org/10.1111/ j.1365-2745.2008.01460.x 